\title{
EVALUATION OF SERUM PARAOXONASE AND ARYLESTERASE ACTIVITIES IN ANKYLOSING SPONDYLITIS PATIENTS
}

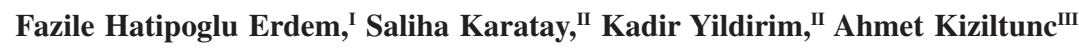

doi: 10.1590/S1807-59322010000200009

\begin{abstract}
Erdem FH, Karatay S, Yildirim K, Kiziltunc A. Evaluation of serum paraoxonase and arylesterase activities in ankylosing spondylitis patients. Clinics. 2010;65(2):175-9.
\end{abstract}

OBJECTIVES: The aim of this study was to investigate the activities of serum paraoxonase and arylesterase in patients with ankylosing spondylitis with respect to those of healthy controls, to assess whether these enzyme levels are related to disease activity and functional capacity.

METHODS: The study included 32 patients with ankylosing spondylitis whose diagnoses were made according to the modified New York criteria as well as 25 healthy controls matched for age and sex. The Bath Ankylosing Spondylitis Disease Activity Index and the Bath Ankylosing Spondylitis Functional Index were applied to the ankylosing spondylitis patients. As laboratory parameters, the erythrocyte sedimentation rate and serum C-reactive protein level were measured in patients and control subjects. Paraoxonase and arylesterase enzyme activities were measured using appropriate methods.

RESULTS: No statistically significant differences $(p>0.05)$ were found between the ankylosing spondylitis patients and controls in terms of serum paraoxonase or arylesterase levels. Furthermore, there was no correlation between clinical and laboratory parameters in patients with ankylosing spondylitis.

CONCLUSION: Serum paraoxonase and arylesterase levels in ankylosing spondylitis patients may not differ from those of healthy controls, and there is no significant correlation between antioxidant parameters and the Bath Ankylosing Spondylitis Disease Activity Index or Bath Ankylosing Spondylitis Functional Index scores in ankylosing spondylitis patients. Further research is needed to provide deeper understanding of this disease.

KEYWORDS: Ankylosing Spondylitis; Paraoxonase; Arylesterase; Antioxidant enzymes; Oxidative stress.

\section{INTRODUCTION}

Ankylosing spondylitis (AS), an inflammatory arthritis of the spine, is the prototype HLA-B27-associated seronegative spondylarthritis. ${ }^{1}$ Although several studies have examined the pathogenesis of AS, the disease is not yet completely understood. Multifactorial mechanisms are believed to be

\footnotetext{
${ }^{\text {I }}$ Department of Physical Medicine and Rehabilitation, Sifa Hospital - Erzurum, Turkey

II Department of Physical Medicine and Rehabilitation, Medical Faculty, Ataturk University - Erzurum, Turkey

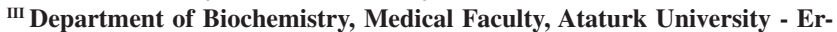
zurum, Turkey

Email: fazilehe@hotmail.com

Tel.: $904423290000 / 3168$

Received for publication on September 08, 2009

Accepted for publication on November 24, 2009
}

responsible for the etiopathogenesis of AS.

Paraoxonase (PON), an enzyme produced by the liver, is associated with high-density lipoprotein particles and is known to have an antioxidant function..$^{2-4}$ In humans, the PON gene family has three members (PON1, PON2, and PON3) that are located on chromosome 7q21.3-22.1.5 The physiological roles and natural substrates of these enzymes are not well known. ${ }^{6}$ PON1 has three known enzymatic molecules, including PON, arylesterase (ARE), and dyazoxonase. PON1 hydrolyzes organophosphates such as paraoxon, hydrolyzes aromatic esters such as phenylacetate, and also decreases the accumulation of lipid peroxidation products. $^{7}$

ARE, a thiol enzyme, is reactivated by 2-mercaptoethanol and cysteine but not by reduced glutathione. ARE acts on phenyl acetate to release phenol, which can produce a stable 
indophenol dye with 4-aminoantipyrine and potassium ferricyanide. ${ }^{8}$ Human serum PON1 and ARE are both esterase enzymes that have lipophilic antioxidant characteristics. ${ }^{9}$ These enzymes play a role in decreasing oxidative stress. PON1 in particular is an important endogenous free radical scavenging system in the human body. ${ }^{10}$ Serum PON1 acts in conjunction with ARE to function as a single enzyme. ${ }^{6,11}$

Recently, a number of studies investigated serum PON and ARE activities in response to inflammatory arthritic conditions such as rheumatoid arthritis (RA), psoriasis, and systemic lupus erythematosus (SLE) with conflicting results. ${ }^{2,12-17}$ To the best of our knowledge, serum PON and ARE activities have not previously been assessed in patients with AS. Therefore, the aim of the present study was to assess whether PON and ARE levels may be related to disease activity and functional capacity in AS patients.

\section{MATERIALS AND METHODS}

Thirty-two patients with AS and 25 sex- and agematched healthy controls were enrolled in the study. The diagnosis of AS was made according to the modified New York criteria. ${ }^{18}$ Patients with AS consumed non-steroidal anti-inflammatory drugs, but no TNF- $\alpha$ inhibitory drugs, during this study. In addition, five patients with peripheral involvement were taking sulphasalazine.

Controls had no systemic disease. None of the participants in the present study was obese, nor were any of them taking lipid lowering agents or antioxidant drugs. None of the patients or controls was a smoker or consumed alcohol.

We used the Bath Ankylosing Spondylitis Disease Activity Index (BASDAI) and the Bath Ankylosing Spondylitis Functional Index (BASFI) questionnaires for clinical assessment of the patients with AS. These two selflimited questionnaires are the gold standard for measuring disease activity and functional capacity in AS patients. The BASDAI consists of a 1 through 10 scale (one indicating no problem and 10 indicating the worst problem) that is used to answer six questions pertaining to the five major symptoms of AS (fatigue, spinal pain, joint pain, and enthesitis, as well as morning stiffness duration and severity). ${ }^{19}$ The BASFI also has a 1 through 10 scale (1 indicating easy and 10 indicating impossible) and consists of ten questions, eight of which relate to the functional capacity of patients and two of which relate to the patient's ability to cope with everyday life. ${ }^{20}$

This study was performed in accordance with the ethical standards set by the Declaration of Helsinki and was approved by the local ethics committee.

Laboratory assessments: All participants were analyzed in terms of complete blood count and erythrocyte sedimentation rate (ESR), as well as C-reactive protein (CRP), serum PON, and ARE levels. All venous blood samples were obtained following an overnight fast. The serum was then separated from blood cells by centrifugation and immediately stored at $-80^{\circ} \mathrm{C}$ until analysis.

The ESR levels were determined according to the Westergren method. A nephelometric method was used for measuring CRP levels (Beckman Array Protein System, USA).

Measurement of PON1 and ARE activities: PON1 activities were measured using diethyl-0-pnitrophenylphosphate as a substrate. Assays were made without additional $\mathrm{NaCl}$ (baseline activity) and with $1 \mathrm{~mol} / \mathrm{L}$ $\mathrm{NaCl}$ included in the assay buffer (salt-stimulated activity), by following the formation of p-nitrophenol (assessed by the absorbance at $405 \mathrm{~nm}$ ) for $5 \mathrm{~min}$. The assay buffer contained $0.125 \mathrm{~mol} / \mathrm{L}$ Tris- $\mathrm{HCl}$ ( $\mathrm{pH} 8.5$ ), $1.25 \mathrm{mmol} / \mathrm{L} \mathrm{CaCl}_{2}$, and, for each set of assays, $6 \mathrm{mmol} / \mathrm{L}$ of a freshly prepared paraoxon (O,O-diethyl-0-p-nitrophenylphosphate; Sigma Chemical Co) substrate solution and $1 \mathrm{~mol} / \mathrm{L} \mathrm{NaCl}(\mathrm{pH} 8.5)$. The paraoxon stock solution was handled very cautiously using protective measures. The assay tube contained $750 \mu \mathrm{L}$ of Tris buffer, $50 \mu \mathrm{L}$ of serum (diluted 1:2 with water), and $200 \mu \mathrm{L}$ of $6 \mathrm{mmol} / \mathrm{L}$ paraoxon. The enzymatic reaction was started at $37^{\circ} \mathrm{C}$ by the addition of the substrate solution. Using a Techcomp 8500 II Spectrophotometer, absorbance was continuously monitored at $405 \mathrm{~nm}$ and $25^{\circ} \mathrm{C}$. One unit of PON1 activity was defined as the enzyme quantity that disintegrated $1 \mu \mathrm{mol}$ of paraoxon substrate in 1 minute. ${ }^{21,22}$ The percent stimulation of PON1 was calculated as follows:

[(PON1 activity with $1 \mathrm{~mol} / \mathrm{L} \mathrm{NaCl}$ )-(basal activity) / basal PON1 activity] x100. ${ }^{23}$

ARE activity was measured using phenylacetate as the substrate. The assay tube contained $750 \mu \mathrm{L}$ of $0.1 \mathrm{~mol} / \mathrm{L}$ Tris- $\mathrm{HCl}$ at $\mathrm{pH} 8.5,1 \mathrm{mmol} / \mathrm{L} \mathrm{CaCl}_{2}, 125 \mu \mathrm{L}$ of $12 \mathrm{mmol} / \mathrm{L}$ phenylacetate, and $125 \mu \mathrm{L}$ of serum (diluted 1:10 with water ). The increase in absorbance was continuously recorded at $270 \mathrm{~nm}$ and $37^{\circ} \mathrm{C}$. The units were expressed as millimoles of phenylacetate hydrolyzed per minute.

Statistical analysis: The statistical analysis was performed using the SPSS 11.0 package program. Differences between groups were analyzed using the MannWhitney U test. Correlation analyses were performed using Pearson's correlation test. A p-value of less than 0.05 was considered to be statistically significant.

\section{RESULTS}

The AS group was comprised of 32 patients; nine were female and 23 male. The mean age of these patients was 33 years (range 20-65), and the disease duration was 8.13 years 
Table 1 - Demographic data as well as clinical and laboratory findings in patients with AS and healthy controls

\begin{tabular}{llll}
\hline & AS group & Control group & P values \\
\hline Sex (male/female) & $(23-9)$ & $(18-7)$ & $\mathrm{ns}$ \\
Age (years) & $30(20-65)$ & $28(20-56)$ & $\mathrm{ns}$ \\
Disease duration (year) & $6(1-25)$ & - & - \\
PON (U/ml) & 292096.6 & 320699.7 & $\mathrm{~ns}$ \\
& $(105083.5-979591.8)$ & $(101563.7-967930.0)$ & \\
ARE (mmol pha/min) & 219847.3 & 197862.6 & $\mathrm{~ns}$ \\
ESR (mm/h) & $(146564.9-952671.8)$ & $(102595.4-952671.8)$ & \\
CRP $(\mathrm{mg} / \mathrm{dl})$ & $16.5(3-58)$ & $10(3-23)$ & $<0.05$ \\
BASDAI & $0.9(0.3-2.9)$ & $0.5(0.3-1.1)$ & $\mathrm{ns}$ \\
BASFI & $2.9(0.2-6)$ & - & - \\
\hline
\end{tabular}

AS: ankylosing spondylitis, ESR: erythrocyte sedimentation rate, CRP: C-reactive protein, PON: paraoxonase, ARE: arylesterase, BASDAI: Bath Ankylosing Spondylitis Disease Activity Index, BASFI: Bath Ankylosing Spondylitis Functional Index. ns: not significant

(range 1-25). In the control group ( $\mathrm{n}=25)$, seven healthy volunteers were female and the others male. The mean age of the control group was 30.28 years (range 20-56). There was no statistically significant difference between patients and controls with regard to demographic data $(\mathrm{p}>0.05)$ (Table 1).

When laboratory findings were compared between the AS and control groups, the ESR but not CRP levels differed significantly between the AS and control group $(\mathrm{p}<0.05)$. When compared to the healthy controls, there was no statistically significant difference in serum PON or ARE levels for patients with AS ( $p>0.05)$ (Table 1). In addition to these findings, we found no correlations among BASDAI and BASFI scores, serum PON, or ARE values in the AS group in the present study. Finally, there were no statistically significant correlations between serum PON and ARE levels or demographic variables (e.g., gender or disease duration).

\section{DISCUSSION}

AS is a chronic, progressive inflammatory disease of unknown etiology. The inflammation primarily affects the axial skeleton, peripheral joints, and extra-articular structures. The pathophysiological basis of AS has not yet been well identified, but immunological mechanisms have been implicated. ${ }^{24}$ Various functions of neutrophils have been shown to be enhanced in AS; these stimulated neutrophil functions mediate oxidative stress, which may have an important role in the pathogenesis of AS. ${ }^{25-27}$

Oxidative stress describes situations in which the production of damaging oxidants exceeds the organism's capacity to neutralize them. ${ }^{26-28} \mathrm{~A}$ decisive role of oxidative stress in inflammatory diseases like AS has not yet been fully elucidated. However, reactive oxygen species produced by activated neutrophils during inflammatory reactions play important functions in the pathogenesis of many inflammatory diseases. ${ }^{24,29}$ Inflammatory reactions trigger oxidative stress that leads to increased oxidant levels, which in turn decrease the level of antioxidants. The antioxidant defense system is responsible for protecting cells against the potentially harmful effect of oxidizing agents ${ }^{30,31}$

In addition to these findings, a limited number of studies investigated the association between the pathogenesis of AS and oxidative stress. For example, Ozgocmen et al. ${ }^{32}$ reported that oxidative stress and lipid peroxidation were accelerated in untreated patients with active AS but found no significant correlation between oxidant/antioxidant levels and disease activity. In another study, Karakoc and coworkers ${ }^{24}$ indicated that increased oxidant and decreased antioxidant capacity might be related to the pathogenesis of AS, but again no significant correlation between antioxidant/ oxidant parameters and disease activity was found. These results are in part also comparable to our findings in the present study. We found no statistically significant difference in antioxidant enzyme levels in AS patients upon comparison to healthy controls and also detected no significant correlation between antioxidant parameters and disease activity.

However, various other reports in the medical literature have indicated alterations in serum PON and ARE activities for patients with different rheumatic diseases, such as RA, psoriasis, SLE, and Behcet's disease., ${ }^{2,12}$ In many of these studies, PON and ARE activities were reported to be significantly lower in patients with rheumatic diseases than in healthy controls. ${ }^{2,12-16}$ In another study, Kiss and coworkers ${ }^{16}$ indicated that ARE activity in patients was not different from that of controls, despite reduced PON activity 
in patients with SLE. In contrast, Toker et al. ${ }^{17}$ reported that serum PON1 and ARE activities were significantly higher in patients with psoriasis than in controls. Thus, the range of findings remains complicated and controversial. To the best of our knowledge, the present study is the first to assess serum PON and ARE activities in patients with AS. We found no significant difference in serum PON and ARE activities in patients with AS when compared to those of healthy controls. In addition, there was no significant correlation among antioxidant parameters, disease activity, or the patient's functional ability.

\section{CONCLUSIONS}

Serum PON and ARE activities may be within normal ranges and may not be associated with disease activity and functional capacity in patients with AS. Further research is needed to provide a deeper understanding of this disease.

\section{REFERENCES}

1. Felson DT. Epidemiology of the rheumatic disease. In Kopman WJ(ed). Arthritis and Allied Conditions, A Textbook of Rheumatology. Philadelphia: Lippincott Williams\&Wilkins, 2001:3-38.

2. Bodolay E, Seres I, Szodoray P, Csipo I, Jakap Z, Vegh J, et al. Evaluation of paraoxonase activity in patients with mixed connective tissue disease. J Rheumatol. 2008;35:237-43.

3. Furlong CE. Genetic variability in the cytochrome P450-paraoxonase 1 (PON1) pathway for detoxication of organophosphorus compounds. J Biochem Mol Toxicol. 2007;21:197-205.

4. Chait A, Han CY, Oram JF, Heinecke JW. Lipoprotein-associated inflammatory proteins: marker sor mediators of cardiovascular disease? J Lipid Res 2005;46:389-403.

5. Draganov DI, Teiber JF, Speelman A, Osawa Y, Sunahara R, La Du BN. Human paraoxonases (PON1, PON2, and PON3) are lactonases with overlapping and distinct substrate specificities. J Lipid Res. 2005;46:1239-47.

6. Precourt LP, Seidman E, Devlin E, Amre D, Deslandres C, Dominguez $\mathrm{M}$, et al. Comparative expression analysis reveals differences in the regulation of intestinal paraoxonase family members. Int J Biochem \& Cell Biol. 2009;41:1628-37.

7. Aslan M, Kosecik M, Horoz M, Selek S, Celik H, Erel O. Assessment of paraoxonase and arylesterase activities in patients with iron deficiency anemia. Atherosclerosis 2007;191:397-402.

8. Karakaya A, Suzen S, Sardas S, Karakaya AE, Vural N. Analysis of the serum paraoxonase/arylesterase polymorphism in a Turkish population. Pharmacogenetics 1991;1:58-61.

9. Serdar Z, Aslan K, Dirican M, Sarandol E, Yesilbursa D, Serdar A. Lipid and protein oxidation and antioxidant status in patients with angiographically proven coronary artery disease. Clin Biochem. 2006;39:794-803.

10. Elkiran ET, Mar N, Aygen B, Gursu F, Karaoglu A, Koca S. Serum paraoxonase and arylesterase activities in patients with lung cancer in a Turkish population. BMC Cancer. 2007;7:48-55.

11. Gan KN, Smolen A, Eckerson HW, La Du BN. Purification of human serum paraoxonase/arylesterase. Evidence for one esterase catalyzing both activities. Drug Metab Dispos. 1991;19:100-6.

12. Isik A, Koca SS, Ustundag B, Celik H, Yildirim A. Paraoxonase and arylesterase levels in rheumatoid arthritis. Clin Rheumatol. 2007;26:3428.
13. Delgado Alves J, Ames PR, Donohue S, Stanyer L, Nourooz-Zadeh J, Ravirajan C, et al. Antibodies to high-density lipoprotein and beta2glycoprotein I are inversely correlated with paraoxonase activity in systemic lupus erythematosus and primary antiphospholipid syndrome. Arthritis Rheum. 2002;46:2686-94.

14. Tanimoto N, Kumon Y, Suehiro T, Ohkubo S, Ikeda Y, Nishiya K, et al. Serum paraoxonase activity decreases in rheumatoid arthritis. Life Sci. 2003;72:2877-85.

15. Karakucuk S, Baskol G, Oner AO, Baskol M, Mirza E, Ustdal M. Serum paraoxonase activity is decreased in the active stage of Behçet's disease. Br J Ophthalmol. 2004;88:1256-8.

16. Kiss E, Seres I, Tarr T, Kocsis Z, Szegedi G, Paragh G. Reduced paraoxonase 1 activity is a risk for atherosclerosis in patients with systemic lupus erythematosus. Ann N Y Acad Sci. 2007;1108:83-91.

17. Toker A, Kadi M, Yildirim AK, Aksoy H, Akçay F. Serum lipid profile paraoxonase and arylesterase activities in psoriasis. Cell Biochem Funct. 2009;27:176-80.

18. van der Linden S, Valkenburg HA, Cats A. Evaluation of diagnostic criteria for ankylosing spondylitis. A proposal for modification of the New York criteria. Arthritis Rheum. 1984;27:361-8.

19. Garrett S, Jenkinson T, Kennedy LG, Whitelock H, Gaisford P, Calin A. A new approach to defining disease status in ankylosing spondylitis: The Bath Ankylosing Spondylitis disease activity index. J Rheumatol. 1994;21:2286-91.

20. Calin A, Garrett S, Whitelock H, Kennedy LG, O'Hea J, Mallorie P, et al. A new approach to defining functional ability in ankylosing spondylitis: The development of the Bath Ankylosing Spondylitis Functional Index. J Rheumatol. 1994;21:2281-5.

21. Furlong CE, Richter RJ, Min WK, Kim JQ. Genetic variations of the paraoxonase gene in patients with coronary artery disease. Clin Biochem. 2001;34:475-81.

22. Eckerson HW, Romson J, Wyte C, La Du BN. The human serum paraoxonase polymorphism: identification of phenotypes by their response to salts. Am J Hum Genet. 1983;35:214-27.

23. Eckerson HW, Wyte CM, La Du BN. The human serum paraoxonase/ arylesterase polymorphism. Am J Hum Genet. 1983;35:1126-38.

24. Karakoc M, Altindag O, Keles H, Soran N, Selek S. Serum oxidativeantioxidative status in patients with ankylosing spondylitis. Rheumatol Int. 2007;27:1131-4. 
25. Wendling D, Didier JM, Vuitton DA. The phagocyte oxidative metabolism function in ankylosing spondylitis. Rheumatol Int. 1991;11:187-9.

26. Yazici C, Köse K, Calis M, Kuzugüden S, Kirnap M. Protein oxidation status in patients with ankylosing spondylitis (concise report). Rheumatology. 2004;43:1235-9.

27. Ho KJ, Chen PQ, Chang CY, Lu FJ. The oxidative metabolism of circulating phagocytes in ankylosing spondylitis: determination by whole blood chemiluminescence. Ann Rheum Dis. 2000;59:338-41.

28. Isik A, Koca SS, Ustundag B, Selek S. Decreased total antioxidant response and increased oxidative stress in Behcet's disease. Tohoku J Exp Med. 2007;212:133-41.
29. Ozgocmen S, Sogut S, Fadıllıglu E, Ardicoglu A, Ardicoglu O. Antioxidant status and lipid peroxidation in seminal plasma and spermatozoa of patients with ankylosing spondylitis. Rheumatology. 2003;42:805-7.

30. Weiss SJ. Tissue destruction by neutrophils. N Engl. J Med 1989;320:365-76

31. Young IS, Woodside JV. Antioxidants in health and disease. J Clin Pathol. 2001;54:176-86.

32. Ozgocmen S, Sogut S, Ardicoglu O, Fadillioglu E, Pekkutucu I, Akyol O. Serum nitric oxide, catalase, superoxide dismutase and malondialdehyde status in patients with ankylosing spondylitis. Rheumatol Int. 2004;24:80-3. 